\title{
A TYPOLOGICAL EVALUATION \\ OF ARROW SLITS AMONG ELEMENTS \\ OF MILITARY ARCHITECTURE IN THE MEDIEVAL PERIOD
}

mong the factors affecting the Middle Ages are military siege tech-
niques and technological developments occurring in this area. The
most important reason for such changes in military architecture was the invention of new technologies and techniques which were able to break down fortification walls. ${ }^{1)}$ Technological developments brought about a series of innovations such as: the thickness of Medieval castle walls, forms of bastions, plans of castle gates and the emergence of elements of new military architecture, especially in castle gates ${ }^{2}$. These changes continued into a new age with the development of gunpowder and cannons. Because of these technological innovations, in our study we shall try to examine the arrow slits which played an active role in passive defence during the Middle Ages, together with their presence on castle walls, gates and bastions with different forms of architecture.

The origins of medieval military architecture and techniques of defence and siege were formed in antiquity and basic rules in this area continued to be used throughout the Middle Ages with hardly any changes. Military architecture, which is the subject of our study, can be included in this category. Arrow slits, described in the simplest of words, are those vertical spaces

1) Bennett, Bradbury, Devries, Dickie and Jestice (2011: 196-207).

2) For types of Medieval castle gates, see: (Parlak 2010); For the castles gate types pre medieval era see: Keeley, Fontana and Quick (2007: 62-67). 
opened in order to shoot arrows from the castle walls. Located inside, and used to defend soldiers against the enemy, they are kept as narrow as possible (about $10 \mathrm{~cm}$ in width) with variable length. Slits usually average from 80-90 $\mathrm{cm}$ to 5 meters in height.

In ancient times, arrow slits were placed on the lower levels of fortifications, for example in ancient Greece. Both arrows and sling stones were thrown from these spaces. Arrow slits had an internal 'V'-shaped crosssection to enable shots to be fired in every direction. This cross-sectional shape created a firing arc of approximately 45 degrees and a wide range of vision for the person launching the missile. Some of the slits were planned for the purpose of lighting, as well as for surveillance and shooting. The ones that were opened in order to provide lighting are generally flat or facing one side. The slits that are in existence today, or known to have existed, are 10-12 cm. wide and 1.00-1.10 m. high. ${ }^{3)}$ There are different types of slits such as: 'a flat cross section', 'an angle in one direction', 'two angles in the same direction' and 'an inward and outward V-shaped form'. During this period, marble or stone made cannon ball shots were usually made from the middle or higher floors and the catapults were placed as high as possible to increase the range of fire. Shots were made from the slits or windows on the upper floors. ${ }^{4}$

In ancient Greece, the oldest windows opened for catapults are found in Marsden Messenia, in the west towers of Arkadia Gate and in Khalkis, Aitolia. These windows are $30 \mathrm{~cm}$ in width, and used as V-shaped arrow slits with sharp upper sides. The widespread use of the catapult in ancient Greece began around $370-360 \mathrm{BC} .^{5)}$ The most convenient slit shape is either square or rectangular. Small square windows that are $80 \times 80 \mathrm{~cm}$ in area are sufficient for catapult shots. ${ }^{6)}$

Whereas the Romans and ancient Greeks, used slit type openings in castles, similar examples may be found in Byzantine fortresses ${ }^{7}$, which are also of this type. Many fortified structures in Western Europe originate from Roman civilization. Although it is interesting to note that the earliest Norman castles do not have these kinds of openings, they began to be used from the
3) Akarca (1998:145).
4) Akarca (1998:145).
5) Moving the catapult in the half-round tower at Assos see: McNicoll (1997: 88, fig. 46).

6) Akarca (1998:146).

7) For arrow slits examples in Byzantine Fortifications see: Foss and Winfield (1986). 
end of the 12 th century. ${ }^{8)}$ When we refer to the West, the most common form of arrow slits are vertical slits on the walls of castles. In the centuries following the 12th century, however, together with the use of crossbows, we also find a horizontal opening added to provide space for the better use of crossbows (Fig. 1-2), so the archers would be able to have control at different angles. Thought to be used for cannon balls and firearms, ${ }^{9)}$ round holes began to emerge in the 14th century for the first time in the West (Fig. 3). ${ }^{10)}$ From the 15th century onwards, the use of bows and arrows started to become obsolete with the use of firearms.

When we look at the Islamic world in the East, we discover some rich examples of military architecture. Desert pavilions from the Umayyad period almost remind us of the Roman castrum and the first examples of arrow slits and machicolation may be observed on the outside of the pavilions. Located today within the borders of Jordan, Qasr Kharana is one of the most striking of the desert pavilions in the style of the Umayyad period (the beginning of the 8th century). Designed for ventilation, the slits, especially those located in the front entrance, are quite interesting. In such structures, the decorative facade was considered as being of greater importance than functionality. ${ }^{11)}$ Using these types of building techniques, this pavilion evoked the style of the Sassanids in its adornments and decorations.

In the West, Norman castles do not have slits before the 12th century, whereas the Crusader castles in the East are frequently built with slits. During the Crusades, not only soldiers but also architects and engineers traveled to the Holy Land and had the chance to observe the architectural works and castles there. When the Crusaders came to these lands, they encountered military architectural elements such as the gatehouse, barbican, ditches, portcullis, slits and machicolation in monumental castles and then built their first castles with a new shape and design in this land. ${ }^{12)}$ Crac des Chevaliers (Castle of the Knights, $1142+50$ years) is the most important of these castles. ${ }^{13)}$ Built by Richard the Lion Heart after the First Crusade (1197-1198), Chateau Gaillard (France, 1197-98) was provided with death traps such as: movable

\footnotetext{
8) Jones and Renn (1982: 445).

9) Nossov (2005: 205, 207).

10) Hull (2006: 67).

11) Urice (1987: 36-44).

12) Hampe (2009: 8).

13) Kennedy (1994:145-168).
} 
bridges, barbicans, portcullis-called-door systems, gate houses, ditches, medieval arrow slits and murder holes. ${ }^{14)}$ Thus, for the first time in Europe, castles began to be built using this new military architecture.

When we look at the castles of Anatolia in terms of the form of the arrow slits, we are faced with a variety of subtle changes from region to region. The most common slit form is the simple arrow slit that can be defined as a vertical opening. The width of this type of arrow slit does not generally exceed $10-12 \mathrm{~cm}$ on the outside of the fortress. The height of the slits, however, can show a greater degree of variety. Inside, the width of the slit expands at an angle, allowing an observer to move more freely outside the castle and the defender to throw stones and shoot arrows. Similarly, the same expansion is seen in the slits of the Roman and Byzantine periods. In contrast, however, the slits in the Sassanid structures have the reverse form (Fig. 4). ${ }^{15)}$ In the Ayyubid castles, the slits are situated in an arched niche inside. ${ }^{16)}$ This structure is also frequently replicated in Seljuk and Mamluk castles. Sometimes, slits are even placed in a double-arched niche in two stages. Belonging to the Seljuk era, these types of slits may be observed on the gatehouse used as a doorway to Alanya Castle. ${ }^{17)}$ Seen as a simple vertical shaped opening from the outside, the slit is taken into a two-stage, double-arched niche of bricks (Fig. 5). In the form of a simple opening, these slits can be observed in niches in some instances, such as: Kahta (Adiyaman), Antep, Maras, Urfa, Birecik, Alanya, Antalya and many Medieval Turkish castles (Fig. 6-7). ${ }^{18)}$ Furthermore, these types of slits, defined as simple vertical openings, can form sub-groups with many different variants. In addition to the examples used for firing objects such as arrows, there are also some slits used for ventilation, exhibiting an outward narrow ' $V$ ' shape in the vertical cross. Sometimes, these groups exhibit a ' $V$ ' shape in the horizontal section, while a straight section or vice versa may be encountered in the horizontal cross section. Occasionally, the base of the slit is flat, since it is used by the defender as a place to shoot arrows and launch other missiles. Therefore, only the ceiling has an inclined design as it narrows vertically towards the outside. Some constructions, have a half-dome or vault-like appearance, especially in the Seljuk castles, since

\footnotetext{
14) Gravett (2004: 22-27).

15) Gregory (1995: 154).

16) For form of arrow in Ayyubid Castle, see: Dangles (2004: 189-204).

17) Parlak (2010: 812, fig. 625).

18) Parlak (2010: 814-825, fig. 628-631, 636, 639).
} 
the upper part of the arrow slit, the ceiling, is built towards the belt. In the Ahmedek section of Alanya Castle and the upper section of Nigde Castle, there are examples of a pitched roof. A further type of arrow slit is used more often for lighting. These are very uncommon, and do not allow mobility for the defenders. They exhibit the same cross section inside and outside. It is possible to find examples of this construction in the gatehouse defending the quay of Alanya Castle.

Since arrow slits are built in order to observe the enemy and to defend the castle by shooting arrows at the enemy, in many examples an attempt is made to place them on the surface of the castle walls in secret. In contrast, in some instances, the side facing the facade of the castle wall exhibits a decorative appearance. Some arrow slits observed on Anamur Castle were crowned with round arches of bricks on the upper part. A rectangular frame built with Ashlar stone even highlights the arrow slit. Located on the Byzantine fortification walls of the Anemas Dungeons, these examples of arrow slits reveal a more advanced form of this construction, highlighted with round arches of bricks nested into each other on the top. Arrow slits are also highlighted on the facade of the Ulu Beden/Evli Beden bastion in the Diyarbakur fortification dating from the Artukid period. Some of the slits are built with cut stone and bordered by a rectangular frame, while the rest is crowned with bordered belts at the top, or, as in the example on the side of the gatehouse, are designed with a double-headed eagle and decorated with a series of stalactites. There are further decorated examples in Ajlun Castle from the Ayyubid Period (Fig. 5). Such examples of slit-like simple openings may be seen on the fortification walls of the ruins of Ani, which are the most impressive examples of Armenian Castles, although the examples here appear to have been based on simplicity as much as possible, so as not to attract attention from the outside. Despite the existence of decorative elements on the fortification walls of Ani, there is a lack of decoration on the arrow slits used for defence. In contrast, it is not wrong to say that the arched slits used for decorative purposes on the outside of the castle are usually found in the castles located geographically in the East (Byzantine, Seljuk, Ayyubid).

The outer sides of the arrow slits in Anatolian castles exhibit a quite different appearance. Their diversity of form is both related to their function and the military technology of the period. Owing to the use of standard bows and arrows rather than crossbows in pre-Ottoman Anatolian fortresses, the horizontal opening seen in the western world from the 12th century onwards is not found in the medieval castles of Anatolia. We observed no examples 
of this in any of the Anatolian castles we analysed. Instead, we encountered many different types of arrow slits. In Anamur Castle, the opening for the arrow slit expands at an angle in one direction, while descending at a width of 10-12 cm, making the width of the slit double at the bottom, providing the opportunity to observe the front gate from a wider angle. The expansion of the bowman slit enables the environment to be observed at a wider angle, this expansion being facilitated from the opposite direction of where the observation takes place. These may be found in Anamur Castle, where there are left and right-angled examples, as well as a stepped one in Anamur Castle. There is a further example in Antep Castle, expanded into one of its sides. In contrast, there are also further kinds and numbers of arrow slits, which expand into two sides (Fig. 8-10). The upper portion of most such slits are narrow and the lower portion expands to the bottom at some point. These take forms such as: 'angled, arched, stepped, square, fish-tail shaped, half circular, rectangular and triangular', expanding downwards. In contrast, however, others expand upwards and narrow downwards, although self-protection behind this form of castle wall is more risky. There are some further examples from Diyarbakır and Ravendan castles which have a wider upper portion and a narrower lower portion in the shape of a keyhole (Fig. 11). In the Citadel of Aleppo, a very different type of arrow slit may be encountered. The top and bottom of the slit is narrow; only the middle part is wide. A further type found in the citadels of Antep and Aleppo, as well as in the castles in the West from the time of the Crusaders onwards, is the expansion made from the middle part of the arrow slit, which has been expanded on each side to form a full circle. As a developed decorative application in the Citadel of Aleppo, this type of arrow slit is opened on the outer face of a balcony tapered with a cone. Kahta Castle (in Adiyaman) has a special arrow slit. This is a very rare example (Fig. 11).

In Georgian Castles, the half-cone shaped arrow slits are of a different type, which surge outward from the walls of castles with a triangular crosssection open from their bases. There are examples of these arrow slits in Khertvisi Castle, belonging to the middle of the 14th century, and Ananuri Castle, dating from the 17th century. An example of this can also be observed in Hoşap Castle, belonging to the Mahmudis and dating from 1643, on the road to Van-Başkale in Anatolia. ${ }^{19)}$ Although this type of slit is not peculiar

19) Taş (2001: 30, 35, fig. 4). 
to Anatolia, it is an architectural element that derives from Georgian Architecture (Fig. 12).

While the question of when the Turks used firearms and cannon balls for the first time is rather controversial, it is thought that the Ottoman army used cannon balls in the campaign against the Karamanids in 1388 and the Wars of Kosovo (1389) and Nicopolis (1396). The use of cannon balls during sieges is almost certain during the fourteen-twenties. The Ottoman artillery developed throughout the Balkans. The cannon balls used in the conquest of Istanbul are thought to have been fired by a Hungarian master originally from Transylvania (Romania). ${ }^{20}$ The balls used by Mehmed at the siege of Istanbul marked the beginning of a new era. This technological innovation caused changes in military architecture and brought about the emergence of round shaped arrow slits to facilitate the use of firearms and cannons. It is possible to see examples of this in the castles of Afyon and Anamur (Fig. 13). In Europe, the use of cannon balls and firearms began in $1326^{21)}$ Therefore, it has been possible to find very different types of arrow slits and envisage their widespread use from an earlier date in the West.

As a result, it is also possible to find quite different examples and richness in the diversity of arrow slits in Anatolia. Because of the influence of the surrounding cultures, some exceptional constructions began to emerge. Since crossbows were not common in this region before the Ottomans, there are no horizontal openings in the arrow slits found in Anatolian castles and the form of the vertical axis is confused by some new details. Despite the intention to keep it disguised, there are also examples of arrow slits with arches and jambs. In Anatolian castles, we can even find decorative ones ornamented with figures, which make them different to those found in the West. In this region, the need to provide a horizontal base to facilitate the use of crossbows is the main reason for the use of the form of a cross. In Anatolia, however, there are no examples of such forms, despite their functionality.

20) Nicolle (2013: 35-38).

21) Nossov (2005: 205, 207). 


\section{BIBLIOGRAPHY}

Akarca (1998) = Akarca, Akşidil: Şehir ve Savunmast (City and Its Defence), Türk Tarih Kurumu Yayımları, Ankara 1998.

Bennett, Bradbury, Devries, Dickie and Jestice (2011) = Bennett, Matthew, Bradbury, Jim, Devries, Kelly, Dickie, Iain and Jestice, Phyllis: Dünya Savaş Tarihi: Ortaçă̆ 500-1500-Teçhizat, Savaş Yöntemleri, Taktikler (Fighting Techniques of the Medieval World AD 500-1500-Equipment, Combat Skills and Tactcs), Özgür Kolçak (tr.), I, Timaş Yayınları, İstanbul 2011.

Dangles (2004) = Dangles, Philippe: "La Refortification D'Afamiyya-Qa'lat Al-Mudiq Sous Le Sultanat Ayyoubide D’Alep (Fin XII.-Mi XIII. Siecle), in: La Fortification Au Temps Des Croisades, Nicolas Faucherre, Mesqui Jean et Prouteau Nicolas (ed.), Presses Universitaires de Rennes, Tillon 2004: 189-204.

Foss and Winfield (1986) = Foss, Clive and Winfield, David: Byzantine Fortification: An Introduction, University of South Africa, Pretoria 1986.

Gravett (2004) = Gravett, Christopher: Norman Stone Castles (Europe 950-1204), Osprey Publishing, Great Britain 2004.

Gregory (1995) = Gregory, Shelagh: Roman Military Architecture on the Eastern, I, Amsterdam 1995: 153-154.

Hampe (2009) = Hampe, Jordan: "The Impact of Crusader Upon European Western Castles in the Middle Ages", A Senior Project Submitted in Partial Fulfilment of the Requirement for the Degree of Bachelor of Arts in Archaeological Studies University of Wisconcin-La Crosse May. 2009.

Hull (2006) = Hull, Lise E.: Britain's Medieval Castles, Greenwood Publishing Group, London 2006.

Jones and Renn (1982) = Jones, P.N. and Renn, D.F.: "The military effectiveness of arrow loop: some experiments at White Castle", in: Château Gaillard, 9-10, 1982: 445-456.

Keeley, Fontana and Quick (2007) = Keeley, H. Lawrence, Fontana, Marisa and Quick, Russell: "Baffles and Bastions: The Universal Features of Fortifications", in: fournal of Archaeological Research, 15:1, March 2007: 55-95.

Kennedy (1994) = Kennedy, Hugh: Crusader Castles, Cambridge University Press, New York 1994.

McNicoll (1977) = McNicoll, A.W.: Hellenistic Fortifications: From the Aegean to the Euphrates, Martin Robertson and others (ed.), Clarendon Press, Oxford 1997.

Nicolle (2013) = Nicolle, David: Osmanlı Ordusu: 1300-1774 (Ottoman Military: 1300-1774), Özgür Kolçak (tr.), Türkiye İş Bankası Kültür Yayınları, İstanbul 2013.

Nossov (2005) = Nossov, Konstantin: Ancient and Medieval Siege Weapons, United States of America, 2005.

Parlak (2012) = Parlak, Sevgi: "Ortaçağ dönemi kale kapılarında karşılaşılan iki mimari: Senkendaz ve Haşlama Bacası”, in: XV. Ortaçağ ve Türk Dönemi Kazıları ve Sanat Tarihi Araştırmaları Sempozyumu Bildirileri (19-21 Ekim 2011), Anadolu Üniversitesi Edebiyat Fakültesi Sanat Tarihi Bölümü, Eskişehir 2012: 667-671. 
Parlak (2010) = Parlak, Sevgi: "Osmanlı Öncesi Anadolu Kalelerinde Kapılar" (The Castle Gates From Pre-Ottoman in Anatolia), unpublicated phD thesis, University of Istanbul Technical, Institute of Social Sciences, Deparment of Art History, İstanbul 2010.

Taş (2001) = Taş, Songül: "Hoşap Kalesi Bezemeleri” (The Decorations of Hoşap Castle), Atatürk University, Institute of Social Sciences, Deparment of Turkish Hand Arts, unpublicated ph. thesis, Erzurum 2001.

Urice (1987) = Urice, S.K.: Qasr Kharana in the Transjordan, American School of Oriental Research, Durham/North Caroline 1987. 
Fig. 1. Arrow slit from Corfe Castle (https://tr.pinterest.com/ pin/458382068306440889/
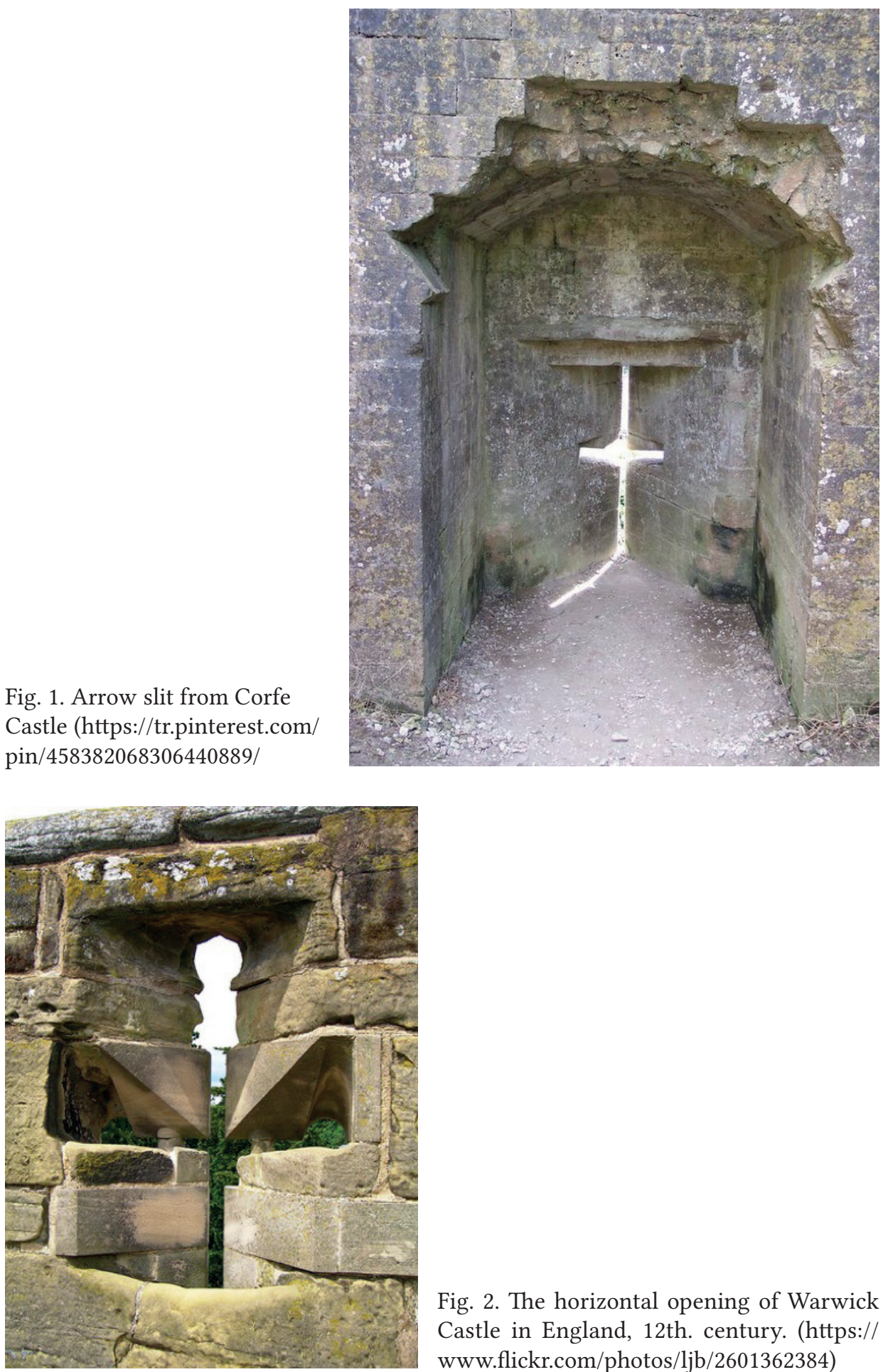

Fig. 2. The horizontal opening of Warwick Castle in England, 12th. century. (https:// www.flickr.com/photos/ljb/2601362384) 

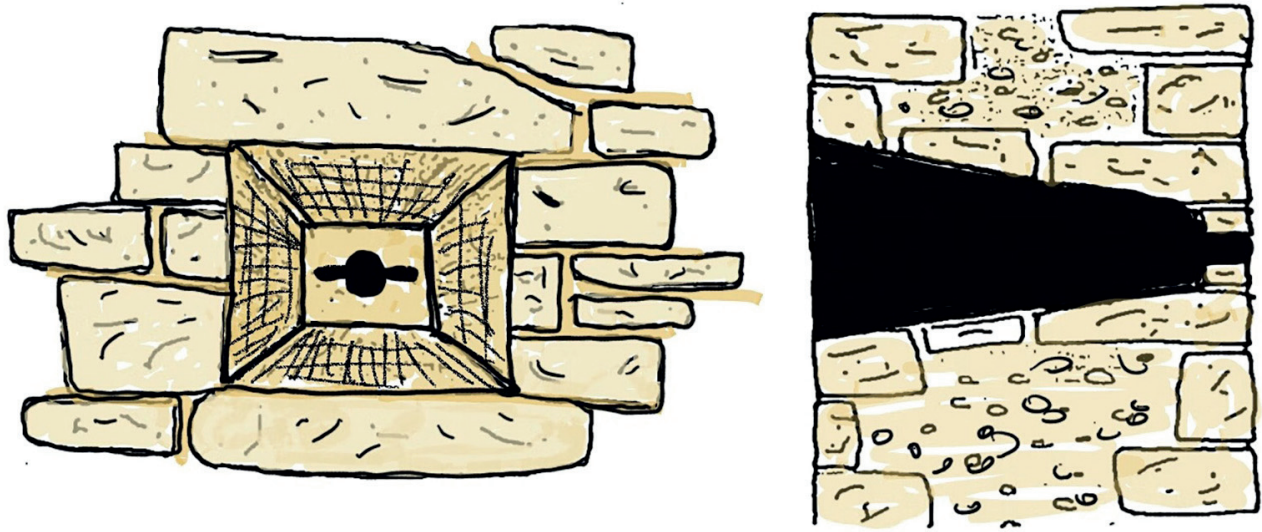

Fig. 3. Drawing of round holes for cannon balls and firearms (Sevgi Parlak, 2014)

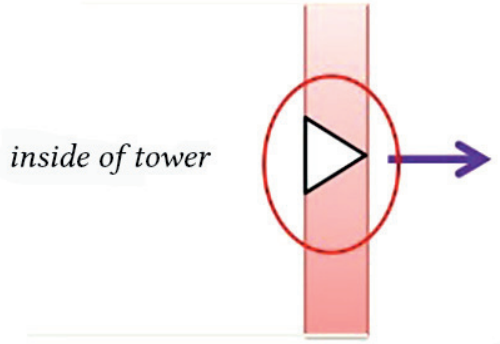

Roman and Byzantine arow slit

\section{inside of tower}

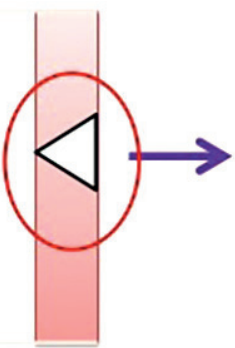

Sassanide arrow slit

Fig. 4. Differences between arrow slits in the Roman, Byzantine and Sassanid Architecture. (Sevgi Parlak, 2014) 

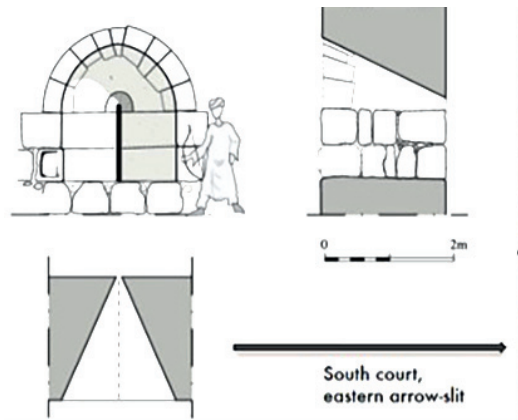

Ajlun Castle
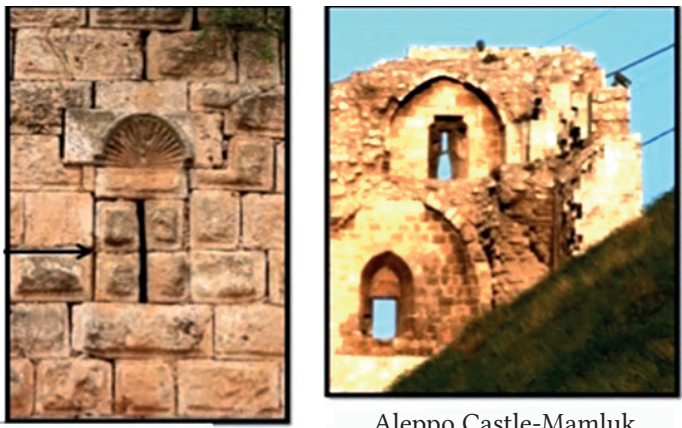

Aleppo Castle-Mamluk

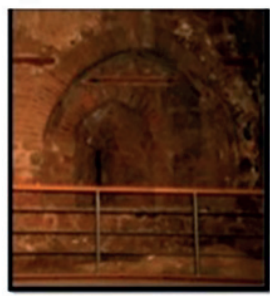

Alanya Citadel gate house, Seljukid

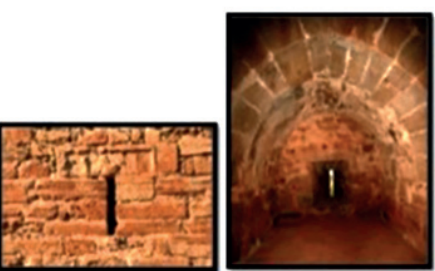

Alanya. Red Tower

(Kizil Kule), Seljukid
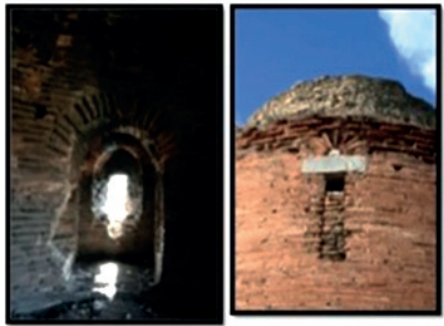

Iznik Fotification-Byzantine period an arrow slit from tower

Fig. 5. Some examples from arched arrow slit (Ajlun Castle from Yovitchtch, 2006: 236, fig. 5; other photos from Sevgi Parlak, 2007-2009)

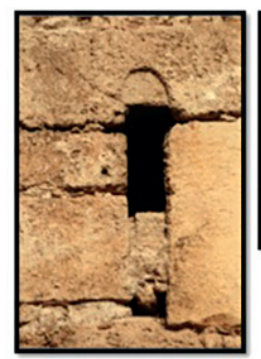

Antalaya Castle Seljukid period

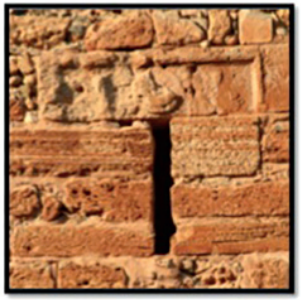

Alyan Castle Seljukid period

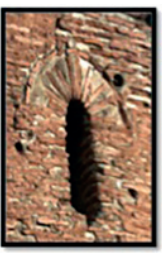

Iznik Fortification, Byzantine period
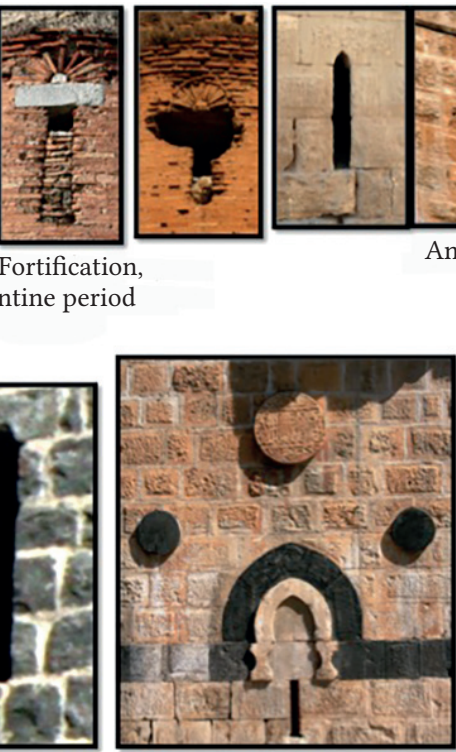

Diyarbakır Castle

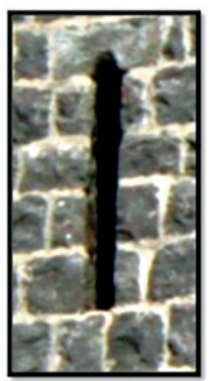

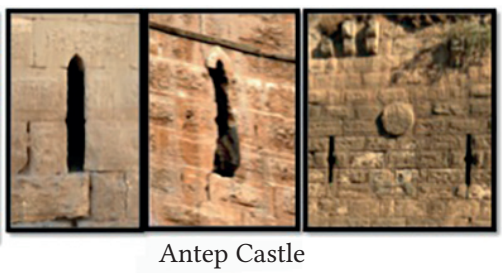
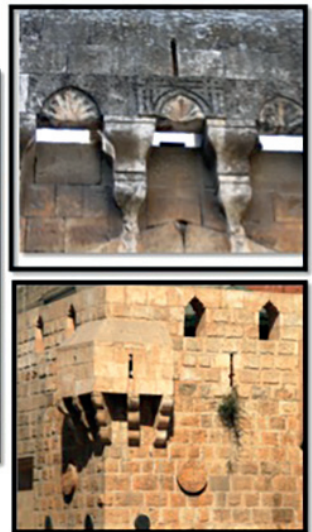

Fig. 6. Some arrow slits examples from Anatolian Medieval Castles (Sevgi Parlak, 2007-2008) 


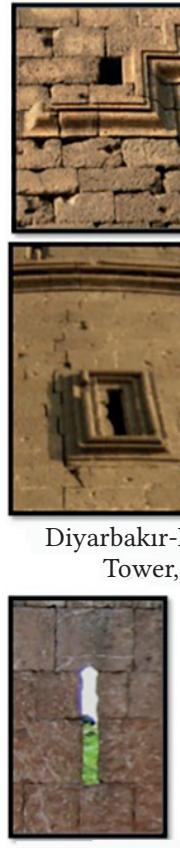

Urfa Castle

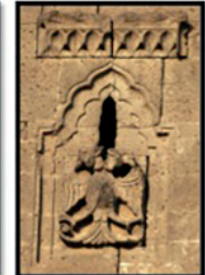

(Ulu) Beden

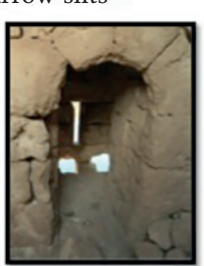

Rumakle

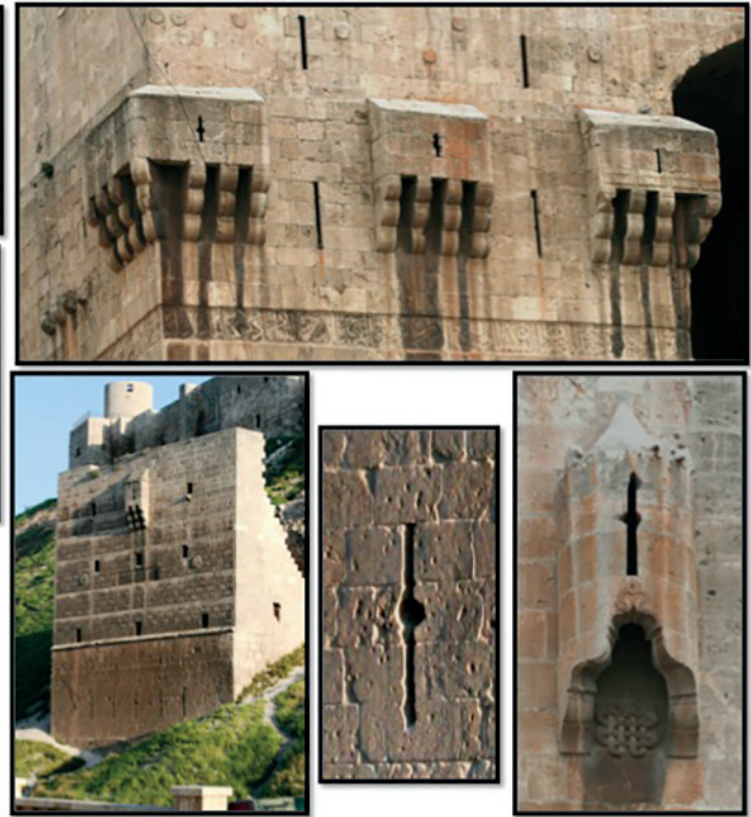

Aleppo Castles

Fig. 7. Arrow slits examples from Diyarbakır, Urfa, Rumkale (Antep) and Aleppo (Syria), (Sevgi Parlak, 2007-2009)
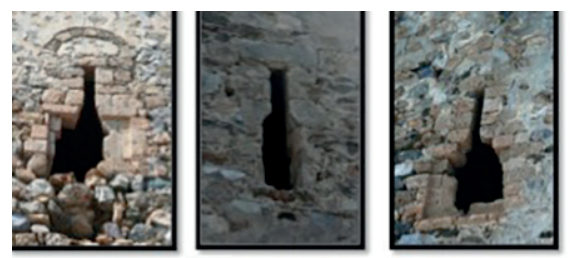

Anamur Castle
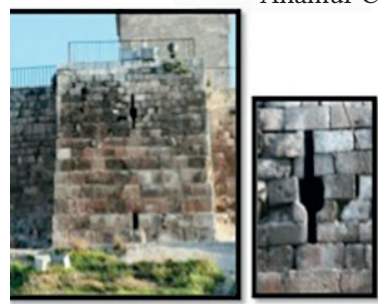

Aleppo Castle
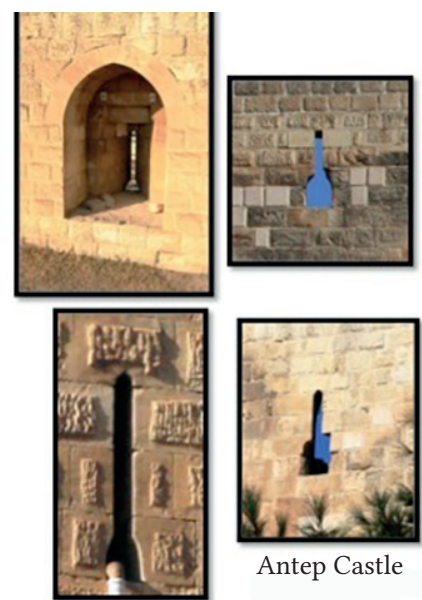

Antep Castle

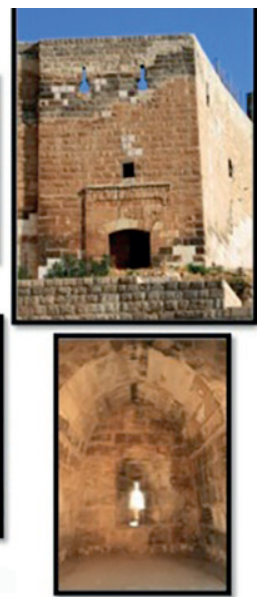

Fig. 8. Arrow slits examples from Anamur (Mersin), Aleppo and Antep Castles (Sevgi Parlak, 2007-2009) 
[32]

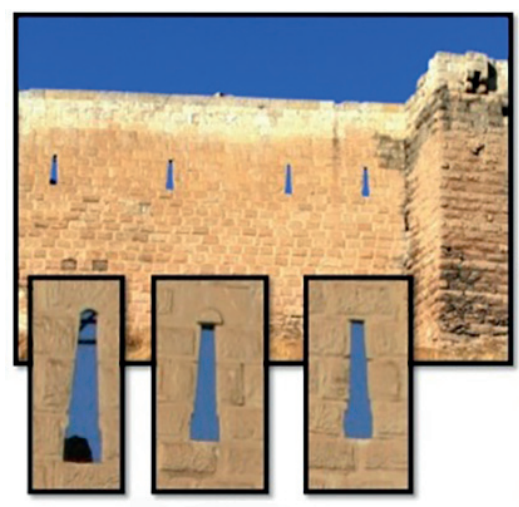

Antep Castle
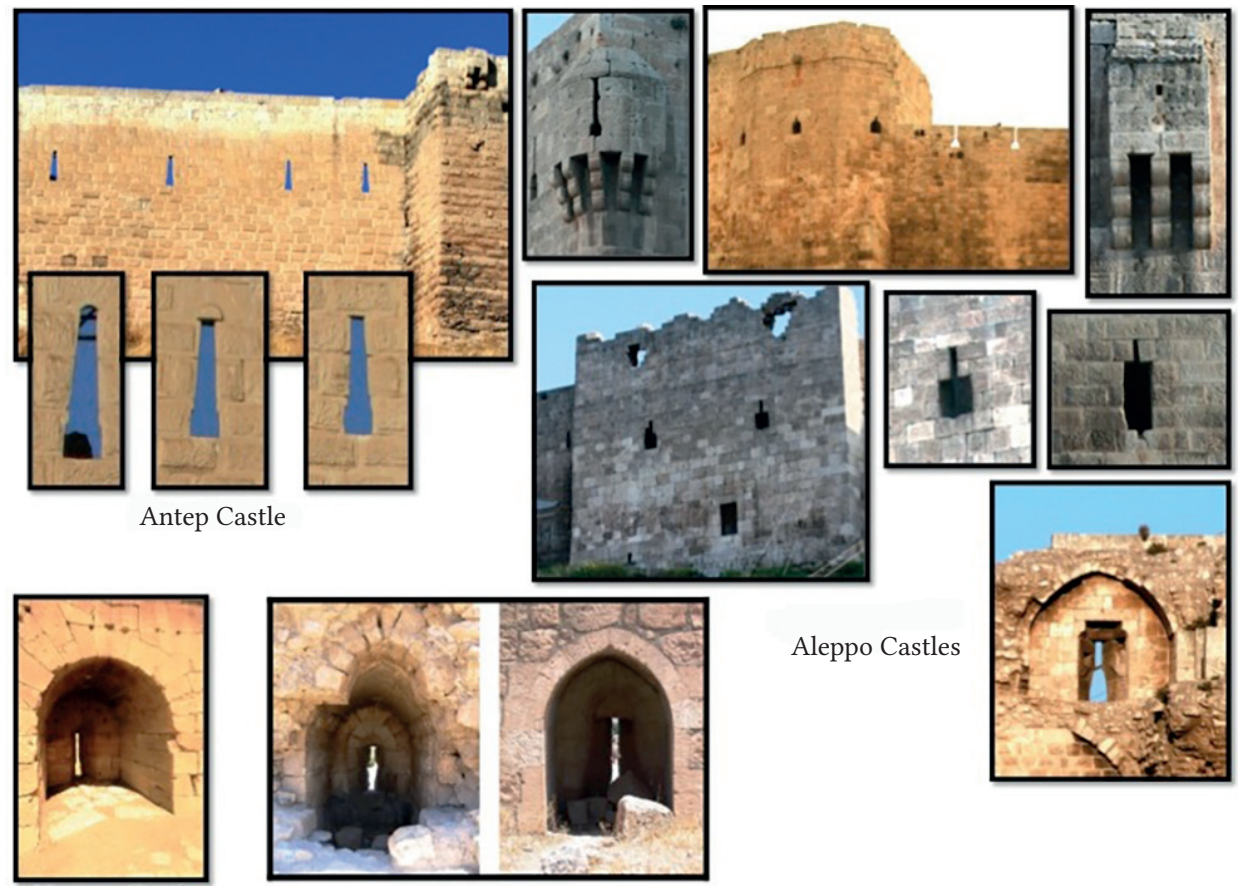

Harran Castle

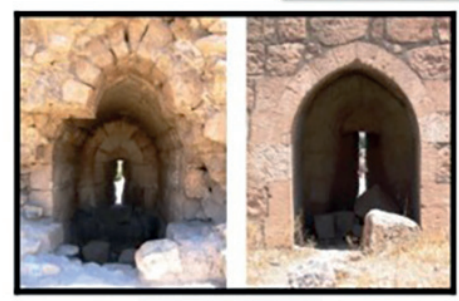

Urfa Castle

Fig. 9. Arrow slits examples from Antep, Urfa, Harran and Aleppo Castles (Sevgi Parlak, 2007-2009)

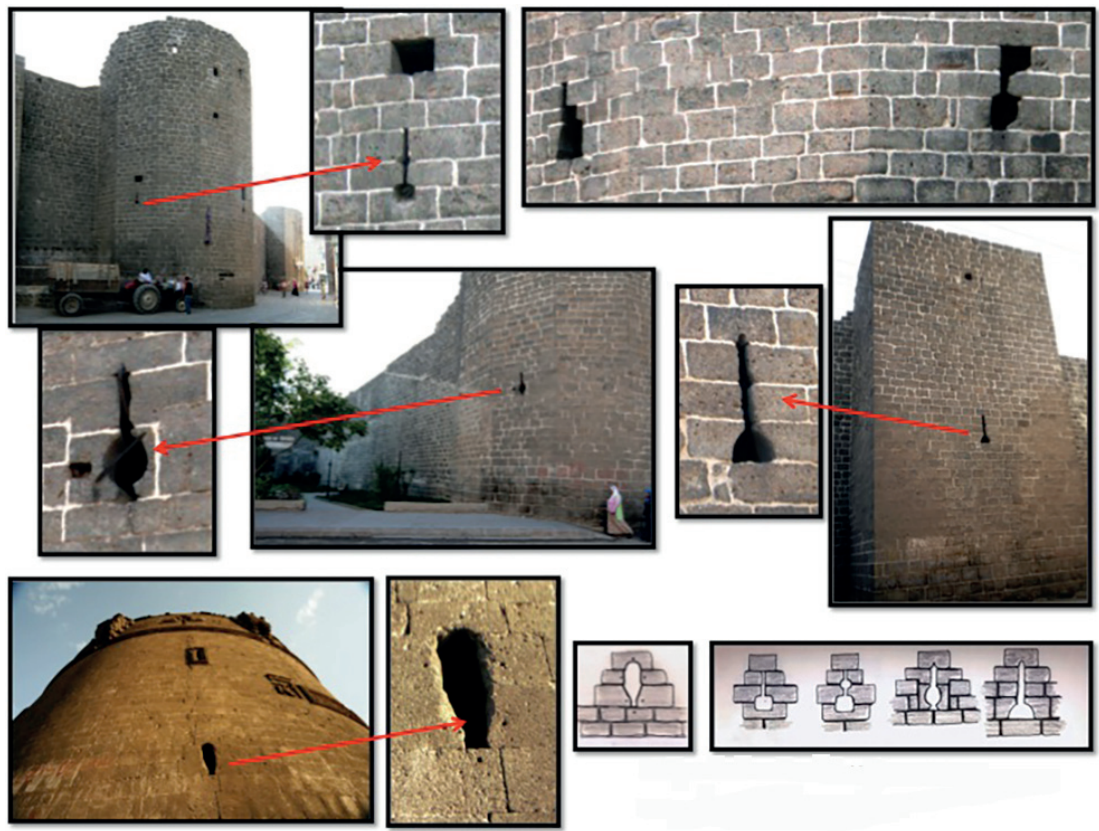

Fig. 10. Arrow slits examples from Diyarbakır Fortifications (Sevgi Parlak, 2007) 

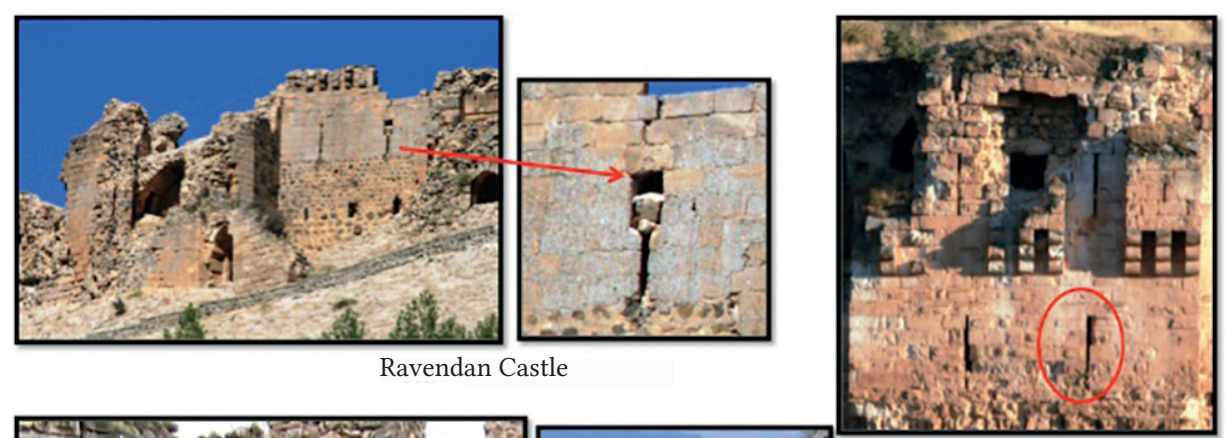

[33]
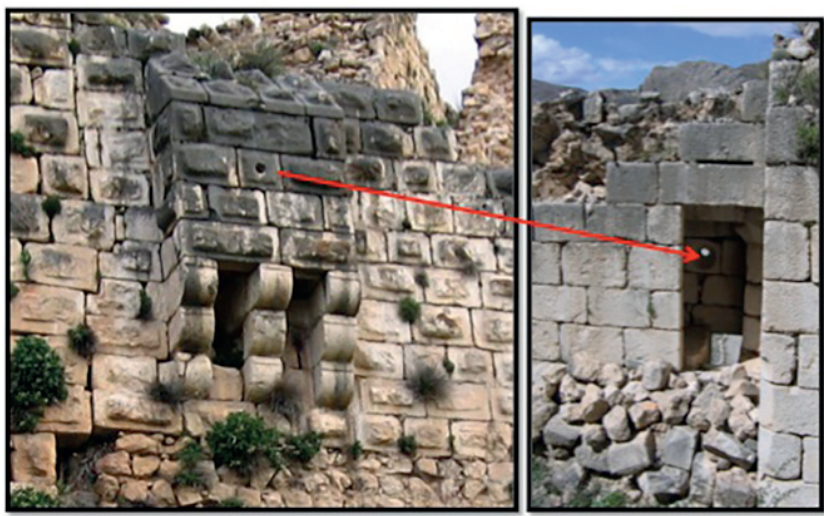

Rumkale Castle

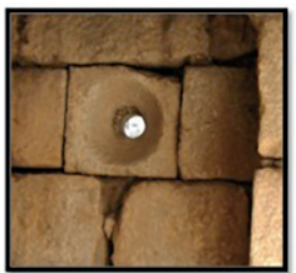

Rumkale Castle

Fig. 11. Arrow slits examples from Ravendan (Kilis/Antep), Rumkale (Urfa) and Kahta (Adıyaman) Castles (Sevgi Parlak, 2008)


Fig. 12. Arrow slit examples from Hoşap (Van) Castle (Sevgi Parlak, 2008) 

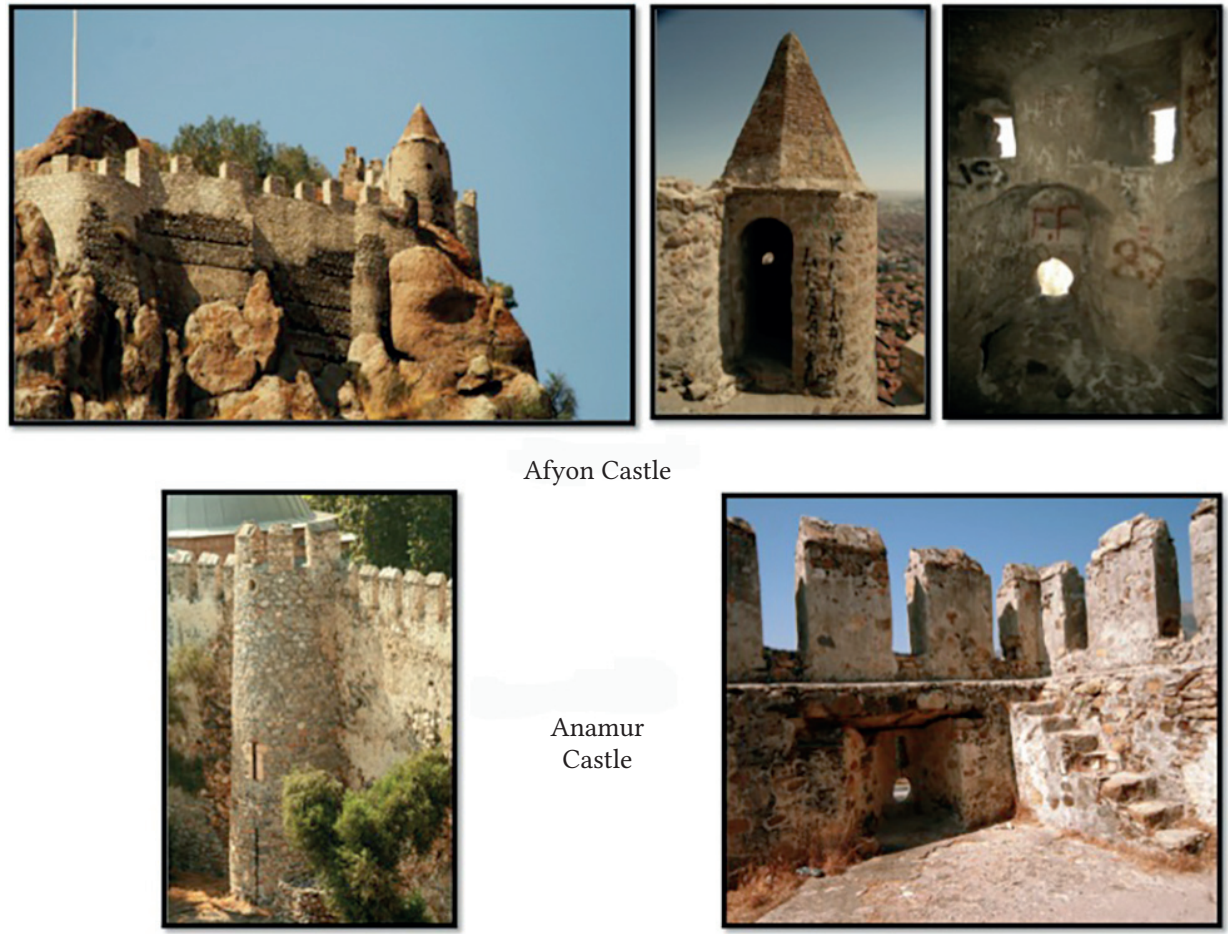

Afyon Castle

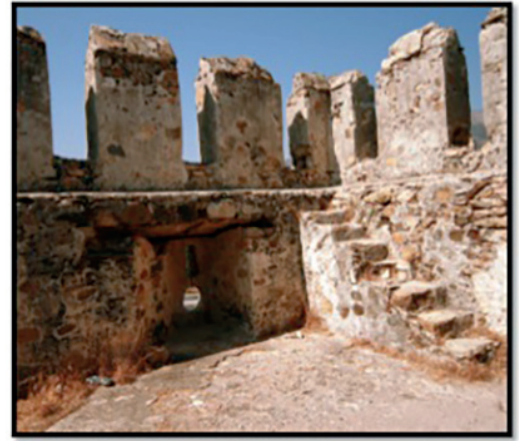

Fig. 13. The round shape arrow slits examples in Afyon and Anamur (Mersin) Castles (Sevgi Parlak, 2008) 